\title{
Pulmonary epithelioid haemangioendothelioma mimicking lung cancer
}

\author{
Naohiro Oda (1) , ${ }^{1,2}$ Yoshinobu Maeda, ${ }^{3}$ Kastuyuki Kiura, ${ }^{1}$ Nobuaki Miyahara ${ }^{1,4}$
}

\begin{abstract}
${ }^{1}$ Allergy and Respiratory Medicine, Okayama University Hospital, Okayama, Japan ${ }^{2}$ Internal Medicine, Fukuyama City Hospital, Fukuyama, Japan ${ }^{3}$ Hematology, Oncology and Respiratory Medicine, Okayama University Graduate School of Medicine Dentistry and Pharmaceutical Sciences, Okayama, Japan ${ }^{4}$ Medical Technology, Okayama University Faculty of Health Sciences Graduate School of Health Sciences, Okayama, Japan
\end{abstract}

\section{Correspondence to} Dr Naohiro Oda; dancingqueen1212@hotmail. com

Accepted 4 February 2021

\section{Check for updates}

(c) BMJ Publishing Group Limited 2021. No commercial re-use. See rights and permissions. Published by BMJ.

To cite: Oda N, Maeda Y Kiura K, et al. BMJ Case Rep 2021;14:e240152. doi:10.1136/bcr-2020240152

\section{DESCRIPTION}

A 63-year-old asymptomatic woman with abnormal chest shadow was referred to our hospital. The patient was a never smoker, and had a history of bronchial asthma and hypertension. Chest CT revealed a $4 \mathrm{~cm}$ diameter tumour in the right upper lobe, two nodules accompanied spicula and pleural indentation in the right $\mathrm{S} 2$ and S6, and right hilar and mediastinal lymphadenopathies (figure 1A,B). Each lesion possessed high fluorodeoxyglucose (FDG) accumulation according to FDG-positron emission tomography (PET)/CT (maximum standardised uptake value: 9.03) (figure 1C,D). Hence, we suspected locally advanced lung cancer. CT-guided lung biopsy revealed epithelioid cells with occasional vacuoles and hyalinised stroma. Tumour cells were positive for CD31 and CD34, and negative for cytokeratin AE1/AE3. These findings led to the diagnosis of a rare low-grade malignant vascular neoplasm called epithelioid haemangioendothelioma (EHE), which makes up $<1 \%$ of all vascular tumours. The lesions were completely resected via right upper lobectomy and partial resection of right lower lobe with reactive changes in lymphadenopathies. No recurrence has been observed for more than 6 years.

Most patients with EHE (64\%) had only one affected organ, with the liver as the most common organ (34\%) followed by the bone (21\%) and lungs (19\%); EHE of the lungs is called pulmonary EHE (PEH). ${ }^{1}$ The typical radiographical findings of $\mathrm{PEH}$

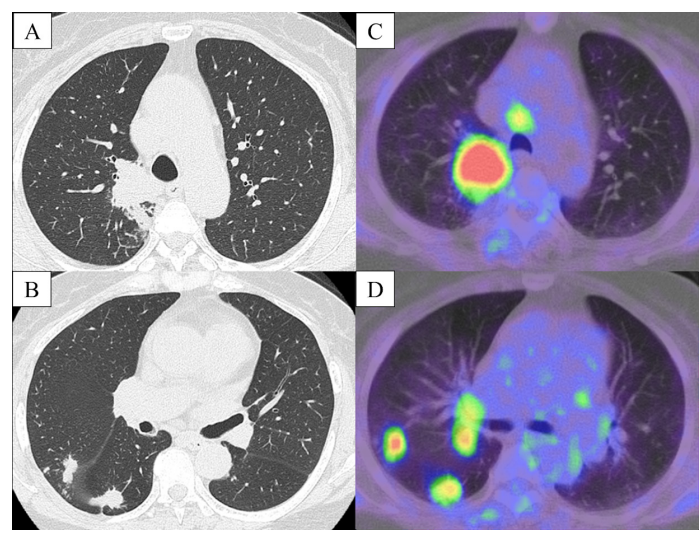

Figure $1 \quad(A, B)$ Chest $C T$ showing a $4 \mathrm{~cm}$ diameter tumour in the right upper lobe, two nodules accompanied spicula and pleural indentation in the right $\$ 2$ and $\$ 6$, and right hilar and mediastinal lymphadenopathies. (C,D) FDG-positron emission tomography/CT showing high accumulation of FDG in each lesion (maximum standardised uptake value: 9.03). FDG, fluorodeoxyglucose.

\section{Learning points}

- Although typical radiographical findings of pulmonary epithelioid haemangioendothelioma (PEH) are reported to be multiple small nodules in both lungs, the images of the present case, including fluorodeoxyglucose-positron emission tomography/CT, revealed a mass and lymphadenopathies, which suggested lung cancer.

- The prognosis of completely resected PEH is good.

are multiple small nodules in both lungs; ${ }^{2}$ therefore, radiographical images resembling primary lung cancer are rare. Generally, PEH development is slow, but it becomes rapid when there is high accumulation of FDG in the lesions. ${ }^{3}$ As a result, FDG-PET/CT results might be a useful indicator to determine whether PEH resection is needed. ${ }^{4}$ Forty per cent of patients survive less than 5 years; ${ }^{5}$ however, there have been cases of long-time survival and spontaneous regression. Symptomatic patients, pleural effusion, and lymph node and liver metastases are associated with poor prognosis. ${ }^{35}$ Nevertheless, the prognosis of completely resected $\mathrm{PEH}$ is good. Therefore, this case highlights the successful treatment of PEH mimicking locally advanced lung cancer.

Contributors NO and NM drafted manuscript; NO, NM, YM and KK, edited and revised manuscript; all authors approved final version of manuscript.

Funding The authors have not declared a specific grant for this research from any funding agency in the public, commercial or not-for-profit sectors.

Competing interests None declared.

Patient consent for publication Obtained.

Provenance and peer review Not commissioned; externally peer-reviewed.

\section{ORCID iD}

Naohiro Oda http://orcid.org/0000-0001-8112-9233

\section{REFERENCES}

1 Lau K, Massad M, Pollak C, et al. Clinical patterns and outcome in epithelioid hemangioendothelioma with or without pulmonary involvement. Chest 2011;140:1312-8.

2 Amin RMS, Hiroshima K, Kokubo T, et al. Risk factors and independent predictors of survival in patients with pulmonary epithelioid haemangioendothelioma. review of the literature and a case report. Respirology 2006;11:818-25.

3 Yi L, Cheng D, Shi H, et al. Pulmonary epithelioid hemangioendothelioma coexisting with pulmonary nodular amyloidosis: case discussion and review of the literature. Int I Clin Exp Med 2014;7:1891. 
4 Watanabe S, Yano F, Kita T, et al. 18F-FDG-PET/CT as an indicator for resection of pulmonary epithelioid hemangioendothelioma. Ann Nucl Med 2008;22:521-4.
5 Dail DH, Liebow AA, Gmelich JT, et al. Intravascular, bronchiolar, and alveolar tumor of the lung (IVBAT). An analysis of twenty cases of a peculiar sclerosing endothelial tumor. Cancer 1983;51:452-64.

Copyright 2021 BMJ Publishing Group. All rights reserved. For permission to reuse any of this content visit https://www.bmj.com/company/products-services/rights-and-licensing/permissions/

BMJ Case Report Fellows may re-use this article for personal use and teaching without any further permission.

Become a Fellow of BMJ Case Reports today and you can:

- Submit as many cases as you like

- Enjoy fast sympathetic peer review and rapid publication of accepted articles

- Access all the published articles

Re-use any of the published material for personal use and teaching without further permission

\section{Customer Service}

If you have any further queries about your subscription, please contact our customer services team on +44 (0) 2071111105 or via email at support@bmj.com.

Visit casereports.bmj.com for more articles like this and to become a Fellow 